\title{
Faith and place: constructing Muslim identity in a secular Lutheran society
}

\author{
Charlotte Fridolfsson and Ingemar Elander
}

\section{Linköping University Post Print}

\section{Tweet}

N.B.: When citing this work, cite the original article.

Original Publication:

Charlotte Fridolfsson and Ingemar Elander, Faith and place: constructing Muslim identity in a secular Lutheran society, 2013, Cultural Geographies, (20), 3, 319-337.

http://dx.doi.org/10.1177/1474474012464024

Copyright: SAGE Publications (UK and US)

http://www.uk.sagepub.com/home.nav

Postprint available at: Linköping University Electronic Press

http://urn.kb.se/resolve?urn=urn:nbn:se:liu:diva-95819 
Faith and place: constructing Muslim identity in a secular Lutheran society

Charlotte Fridolfsson* and Ingemar Elander**

* Department of Behavioral Sciences and Learning Linköping University

SE-581 83 Linköping

Sweden

charlotte.fridolfsson@liu.se

** Centre for Urban and Regional Research

Örebro University

SE-701 82 Örebro

Sweden

ingemar.elander@oru.se (corresponding author)

Telephone: +4619303069 


\begin{abstract}
Non-Christian immigrants coming to Sweden encounter a mainly secular society with a strong Lutheran heritage, as physically symbolised by the more than 3500 church towers scattered throughout the country, often in central locations in cities and villages. In this landscape dotted with Christian landmarks, there are few visible physical spaces linked to the identity of Muslim immigrants. The aim of this article is to analyse the religious and cultural significance that Muslim immigrants attach to the presence or absence of mosques in their neighbourhood. Drawing upon a conceptual framework that distinguishes between physical, mental and social space, the analysis focuses on the meaning of place and the identity attached to the mosques. The empirical basis for the study includes interviews with imams complemented by articles and other written materials published in newspapers and on the internet. In the concluding section, we return to and reflect upon our overarching question: the relationship between faith and place in a multi-religious, multi-ethnic society. As illustrated in the article, mosques not only function as internal markers of religious faith but also serve as arenas where links can be developed to Christian and secular parts of Swedish society. Thus, they are important in providing both bonding and bridging capital for Muslims in Sweden, thus making it possible to develop a Muslim identity in Sweden.
\end{abstract}

Key words: Islam in Sweden, Muslim identity, Mosque, Faith and place, Religion and geography 
Introduction

Migration is one (although not the only) reason for the alleged post-secular turn in western societies. Many immigrants find religion to be an important marker of identity in new surroundings and seek out spaces and places in which they can share and express their faith together with fellow believers. ${ }^{1}$ However, depending on the contextual circumstances, faith in the context of migration can manifest itself in different ways at the individual level: it may unify and isolate religious groups, generate a fundamentalist counter-culture, or encourage migrants to adapt their religious culture to the new country. ${ }^{2}$ Consistent with this view, Kinnvall and Nesbitt-Larking, in their recently published study of the political psychology of globalisation and Muslims in the West, identify three ideal strategies of identity formation among Muslim immigrants: retreatism, essentialism, and engagement. The authors themselves argue in favour of the latter, suggesting that both majority and minority communities in society should strive to become "postnationalist, self-dialogical, and engaged in dialogue with a range of others. Activist, assertive, and agonistic rather than antagonistic”. They conclude that "Muslims are positioned to contribute toward new cosmopolitical potentialities for a renewed pluralistic global order”. ${ }^{3}$

However, adaptation to a new national context may even result in secularisation, as has been the case among Chilean immigrants in Sweden since 1973. ${ }^{4}$ As suggested by a young male immigrant who escaped with his family from Bosnia to a Swedish town in 1992, one’s religious approach in a new country is strongly related to one’s previous experience: "Here are Muslims from many countries. Many newly established groups. What you bring with you from your homeland and your culture influences how you practice your religion.” ${ }^{5}$ This quotation dovetails with the argument posed by Bäckström and Davie regarding David Martin's work: that the "interactions of the religious and secular should rather be seen in the long-term [...] they work themselves out different in different places [...] the shorthand of 'God is back' does not, indeed cannot, do justice to this urgent and complex agenda”. ${ }^{6}$

What about the mosque in the context of Muslim immigration? Introducing a special issue of the Journal of Ethnic and Migration Studies on mosque conflicts in Europe, Jocelyn Cesari states that the mosque

is central to Islam's urban visibility and is the centre of Muslim communal life. It is not only space for prayer but also a 'community centre', where pre-existing networks of solidarity come together and where various rituals that mark Islamic family life - marriage, circumcision, death - take place. ${ }^{7}$ 
She also adds that the mosque

not only expresses the presence of a local Muslim community, it also represents the evolution of Islam from the private to the public sphere. Whereas, in the past, Muslims in Europe were isolated within invisible and private prayer rooms, the mosque openly, publicly and visibly marks on an Islamic presence. ${ }^{8}$

On the other hand, Cesari notes that "except for Friday prayers, special holidays and the month of Ramadan, daily mosque attendance in Europe is generally low”. ${ }^{9}$ This observation again illustrates that Muslim trans-nationalism is multifaceted, including "many and diverse forms to be found in Europe today". ${ }^{10}$ Similarly, Veit Bader points to the "perils of modelling.” The expanding body of immigrants from Muslim countries entering Europe is characterised by "a broad variety of languages, ethnic cultures and religious traditions in addition to differences in class-position, age, citizenship etc." who attempt "to live their practices as minorities under conditions of entrenched but widely diverging regimes of governance of religious diversity". ${ }^{11}$ Consequently, although "the number of articles, books and reports on nearly all aspects of the Muslim presence in Europe has literally exploded”, more detailed studies of Islam in different European contexts are urgently needed if we are to develop a more comprehensive analysis of Islam in Europe. ${ }^{12}$

Despite this wave of publications, the role of mosques in generating transnational Muslim identities has not truly been addressed in the Swedish context ${ }^{13}$. Paradoxically, Sweden is commonly considered to be a very secular society. Despite its long-standing heritage as a Lutheran state, since the mid- $19^{\text {th }}$ century, Sweden has featured a strong, popular free-church movement. Although church membership and attendance in Sweden is declining as in other European countries, post-war value shifts in belief systems toward modernisation and secularisation have also encouraged many people to rediscover religion in a more pluralist and less institutional form. In this type of "patchwork religion,” religion becomes more "invisible” but still remains "a steady part of people's lives"14. Strikingly, as argued by Kinnvall and Nesbitt-Larking, the role of religion in Swedish society "is not debated in any significant depth, which is illustrative of the fact that there is no centralized unit that has been given the responsibility and necessary competence to deal with Islam in all its complexity”. ${ }^{15}$

In addition to the general discussion of secularism and post-secularism, it is notable that religion is not just a matter of evangelisation, saving people's souls, or individual and invisible beliefs. Religion also sometimes serves to meet people's needs in a fundamental social sense, helping poor people to obtain shelter, to defend their legal rights or simply to 
survive. Thus, as governments in Europe struggle to meet their citizens’ needs, new opportunities are arising for involvement by for-profit and non-profit providers of social welfare, including faith-based organisations (FBOs), which are one type of non-governmental organisation that the government uses to complement or replace parts of its public welfare programs. $^{16}$

Sweden differs from most other European countries with regard to the role of FBOs as producers of welfare. From the 1930s onwards, the state (including local governments) began to take over social welfare services that were previously organised by third-sector charities and popular movements: for instance, public child care and care for the elderly as advocated by the women's movement. However, the popular movements and related charities retained their "avant-garde” role in advocacy and innovation to some extent, ${ }^{17}$ and despite an increasing tendency towards reliance on for-profit welfare programs, the Church of Sweden, the City Missions, the Salvation Army and other free churches continue to offer shelter to homeless people, help drug addicts and offer a number of other social services in hospitals, prisons and barracks and in everyday social matters. For the many Muslim immigrants who have entered Swedish society, the Stockholm Mosque and a growing number of other mosques and cellar mosques in many cities also offer welfare services. ${ }^{18}$

The aim of this article is to assess the importance that Muslims attach to the presence of a mosque - its proximity, visibility and utility - for Muslim identity in Sweden. ${ }^{19}$ What meaning in terms of place and identity is attached to mosques, the land on which the mosques were or will be built, and the discourses on Muslim identity as expressed by Muslims in Sweden? How is the Muslim identity constructed and negotiated in the context of mixed attitudes towards Muslim immigrants and Islam as such? Drawing upon the conceptual distinction between physical, mental and social space, we describe the places where mosques are built in terms of their visibility for and proximity to Muslims in Sweden. We draw attention to the various social activities organised by the mosques - their social utility - and examine whether they are predominantly religious and proselytising or address a broader audience, thus indicating the desire to develop a transnational Muslim identity in Sweden. ${ }^{20}$

Officially beginning with the Swedish King Olof Skötkonung’s baptism in approximately the year 1,000, the Christian tradition in Sweden has a millennium-long history. In Swedish 
elementary schools, pupils are taught that the French Benedictine monk Ansgar first preached the Christian gospel in 829 AD to the pagan Vikings residing in the area that is now called Sweden. ${ }^{21}$ Pagan sacrifices were used in tandem with Christian ceremonies for a long period, but in 1210, Erik Knutsson became the first King crowned by a Christian bishop. The event also marked the union between the church and the state, an alliance that would last until year 2000. This religious historic narrative suggests that the conversion to Christianity was smooth and slow. The officially sanctioned story deemphasises the power struggles that occurred between different faiths and attempts to invalidate other interpretations of Sweden's religious past, as documented by frequent Viking trading contacts with the Arabic world before the arrival of Ansgar. ${ }^{22}$

In the 1530s, Swedish King Gustav Vasa joined the reformation and proclaimed Sweden an evangelical kingdom. For a long period, the evangelical faith was compulsory. Foreigners who desired to practice another faith or even another form of Christianity were required to do so behind closed doors. During the 18th and 19th centuries, the less hierarchically organised low and free church movements paved the way for freedom of religion in Sweden, but such freedoms were not formally established until 1951.

Even in the latter part of the $20^{\text {th }}$ century, Sweden was considered homogenous in cultural, ethnical and religious terms, although there has also been considerable diversity due to migration in the past. In addition to the indigenous Sami population, small communities of Roma, Tornedal, and Jewish minorities have lived in Sweden for centuries. From time to time, there has also been a substantial influx of entrepreneurial immigrants from Germany, Scotland, Belgium and other countries. After World War II, waves of refugees and labour migration from Greece, the Baltic countries, Turkey and the former Yugoslavia provided a substantial source of labour for the flourishing Swedish industries and encouraged the expansion of the public welfare system.

Islamic immigrants arriving to Sweden encounter something of a paradox; Sweden is a strongly secular society but also has a strong Lutheran heritage, as physically symbolised by the more than 3,500 Church of Sweden buildings located across the country. There are also thousands of small free church buildings used in the same manner for mass, prayer, baptisms, weddings, funerals or other religious ceremonies. These buildings serve as signposts of place identity and create the impression of Sweden as a religious landscape. Although Sweden is sometimes considered one of the least religious societies in the world ${ }^{23}$, approximately 70 per 
cent of Swedish citizens are members of the Church of Sweden, having become members before year 2000, when the church was still a state institution and membership was obligatory. In other words, these individuals are not active Christians. ${ }^{24}$ Approximately one per cent of the Church of Sweden members cancel their memberships every year, whereas Muslim congregations and the Catholic and Christian Orthodox Churches continue to attract more members. The free churches face declining memberships and try to counter this trend, for example, by merging disparate congregations. ${ }^{25}$

Despite these and other signs of secularism in Swedish society, Muslim immigrants arrive in a landscape that is dominated by Christian landmarks and includes very few visible physical spaces linked to Muslim identity. Imams and other Muslim leaders try to obtain financial resources and suitable places for building mosques or otherwise seek facilities that could function as provisional locations for worship and ceremonies. Since the 1990s, Sweden has received more refugees and asylum seekers than any other European country relative to the size of its population. ${ }^{26}$ Notably, the number of second- and third-generation immigrants is steadily increasing, thus making "Muslims in Sweden” the most accurate term to use in this article. The number of first-generation immigrants coming from Muslim-dominated countries is greater than 300,000 and most of them come from Iraq $(100,000)$, Turkey $(70,000)$ and Bosnia $(70,000)^{27}$. How many of these individuals are practicing Muslims is unclear, as Swedish law does not allow individuals to be registered in terms of their religion and language. Although the estimates vary, it is thought that there are between 110,000 and 150,000 practicing Muslims in Sweden ${ }^{28}$. Less than 5 per cent of the population in Sweden are Muslims, and about 90 per cent of them have arrived after $1985 .^{29}$

Thus, the past few decades of globalisation and immigration have transformed Sweden into a pluralist, multi-ethnic society, generating implications for the range of faiths practiced in the country. However, these changes in the religions of Swedish citizens have not yet had a corresponding impact on the physical presence of faith-based institutions. In year 2010, five different Islamic congregations received financial support from the Swedish Commission for Government Support to Faith Communities. ${ }^{30}$ In addition, the Muslim Adult Education Association Ibn Rushd was explicitly founded on the premise of the Swedish tradition of adult education [folkbildning] and is one of ten Adult Education Associations to receive public funding. Aside from these organisations, there are also a number of non-registered 
congregations for Muslims. ${ }^{31}$ Next we consider the three dimensions of space - physical, mental and social - along which we will explore the practice of Islam in Sweden.

Faith and three dimensions of space

Across the globe, there are "sacred cities" that function as religious centres for believers: Mecca for Muslims, Bodhgaya for Buddhists, Varanasi for Hindus, the Vatican for Catholics, and Jerusalem, to which all three of the monotheistic religions, Christianity, Islam and Judaism, place a claim in their respective holy books. ${ }^{32}$ Aside from these particular cities, most towns and cities feature buildings and other sacred places with which believers from the official or majority religion and some other individuals can identify, finding there a haven for worship and celebration. As stated by Yi-Fu Tuan in his classic work Space and Place: ${ }^{33}$

Evidence from different cultures suggests that place is specific - tied to a particular cluster of buildings at one location - wherever the people believe it to be not only their home but also the home of their guarding spirits and gods.

According to Beaumont, "it is in the urban that the shift from secular to post-secular in terms of public space, building use, governance and civil society is most intensively observed and experienced"; cities "become 'hot spots' or sites for split loyalties and demands, and the negotiation of multiple identities which need to include both religious and secular dimensions”. ${ }^{34}$ However, even in highly secular cities where there may be few officially religious buildings available, faith believers may find places to worship; they may even "build their own 'church' out of parks, gyms and auditoriums”, as Gemma Cruz notes regarding female domestic workers in Hong Kong, most of them from the Philippines. ${ }^{35}$ Thus, the religious or spiritual dimension of place may manifest in somewhat unexpected contexts such as soccer, as illustrated by the text of T-shirts worn by football team supporters: "Liverpool is my religion/Anfield is my church/True believers never walk alone”. ${ }^{36}$

Some theologians inspired by "the spatial turn” in geography, anthropology, literary theory, history and other fields within social science argue that cities themselves are or have the potential to be sacred spaces/places. ${ }^{37}$ This debate is connected with Lefebvre's distinction between "perceived, conceived and lived moments, three aspects of a conceptual triad, equating these with spatial practice, representations of space, and spaces of representation”. 38 Notably, in this quotation, the conceptual triad is discussed in relation to the city, but it can also be applied to the mosque. We can also recall a similar triad introduced by Edward Soja that includes Firstspace, Secondspace and Thirdspace. ${ }^{39}$ In the context of this article, these 
triads are important in the sense that a mosque, whether a real mosque or a cellar mosque, may also be viewed through any one of these three conceptual lenses. As "spatial practice", the mosque is a physical place that Muslim believers more or less regularly frequent for worship, ceremonies and social intercourse. As a "representation of space”, the mosque is the conceived aspect, the meaning given to the mosque by imams and other religious leaders according to their interpretation of the Qur`an. Finally, as “spaces of representation” ("lived space”), it is a question of how mosques "are experienced by citizens and migrants, and may be imaginatively constructed or produced”, i.e. how Islam is perceived and practiced by Muslims in their everyday life. ${ }^{40}$ Notably, the three dimensions of space identified by Lefebvre and Soja can be distinguished from one another only in theory; in real life, they "exist at the same time and are intertwined in a trialectic relation". ${ }^{41}$ Or, in other words, "physical, social and mental spaces intersect and overlap". ${ }^{42}$ Applied to the topic of this article, this means that a mosque is at the same time a physical building, a mental construct, and a place for social intercourse (a social hub). This intimately related triad of spatial dimensions will be addressed in all of the sub-sections that follow, although the focus will shift from the physical dimension to the mental dimension and, finally, to the social dimension.

\subsection{The location of mosques: proximity and visibility}

In most villages, towns and cities, there are buildings and places with which many faith believers can identify and where they can meet to express and share their faith. However, in a country such as Sweden, where Christianity has been the dominant religion for ages, Muslims and other non-Christian immigrants have no such places available to them. Their experience exists in striking contrast to that of Christian immigrants: for example, the Syrian-Orthodox immigrants who escaped Turkey for Sweden in the late $20^{\text {th }}$ century. ${ }^{43}$ Although they did not find churches that were specially designed for worship according to their interpretation of the Christian gospel, Syrian-Orthodox immigrants are at least familiar with the general look and function of the old church buildings in Sweden. Moreover, although these individuals encountered opposition when they endeavoured to build their own churches, they were still able to obtain sufficient local support to succeed. One illustrative example is the case of the Syrian-Orthodox Church close to the Varberga neighborhood in Örebro; the local government quickly approved the proposal in 1990, including the proposed site, despite some local protest. $^{44}$ 
A few years later, the Islamic Cultural Centre in Örebro faced tougher resistance, also from local Christian free church leaders, when it endeavoured to build a provisional mosque in the shape of a community hall (i.e., not a "real” mosque with a minaret) close to the Vivalla neighbourhood in Örebro. ${ }^{45}$ It wasn’t until 2010, after the Islamic Center had resided for years in a small building in the city centre, that the Islamic Center took over a building that had been constructed by Jehovah's Witnesses. The building is located adjacent to the Vivalla neighbourhood, which is inhabited by people with a wide variety of national, ethnic, cultural and religious backgrounds. In both cases, the adherents to the religions obtained the physical space that they required (although, again, this mosque is not a full-fledged one). This provided them with room for worship and ceremonies as well as social activities such as language courses, choir rehearsals, and social meetings for children, housewives, unemployed individuals, and others, as we will return to below.

Most of the Swedish mosques are located in basements of residential buildings in multifamily housing areas or in former industrial locations ("cellar mosques” or "basement mosques”). In this way, they are significantly different from the Christian locations, as stated by Abd al Haqq Kielan, imam and secretary of the Swedish Islamic Academy:

It is important to be able to move up from the lower level and into a real mosque. As long as we are in a basement, we do not really exist. It is important to leave the basement, partly for practical reasons, because down there it is crowded, poorly ventilated and has bad lighting, but also for status reasons. A visible mosque wins prestige and means a lot for integration. Muslims would then feel that we are also part of society and it would be easier to socialize on equal terms. ${ }^{46}$

Another imam says, "Even if there is a local premise, one wants to visit a real mosque". ${ }^{47}$ The quotations by these two Muslim leaders clearly express the importance of the intimately linked relationships between the physical, mental and social dimensions of space.

The difference between a provisional and a real mosque can be illustrated by the case of Skärholmen, a multicultural suburb of Stockholm. The present (spring 2012) mosque is located in an office building in the centre of the suburb. Its 300 square meters are far from sufficient to welcome the many Muslim believers in the area, especially when compared to the 3,000 square meters of the new mosque that is expected to be completed in 2014: "This is something I have longed for in 20 years [...] there should be no doubt what kind of building it is”, says Fikret Tümtürk, chairman of the Skärholmen Islamic Association. However, plans to decorate the mosque in the traditional Swedish Falu-red colour in an attempt to reinforce the 
connection between Swedish culture and Islam have been dismissed as extreme. ${ }^{48}$ The Church of Sweden parish publicly supports the construction of a mosque in the centre, and one of the priests has said the following:

Our congregation thinks that it would be good with a centrally located mosque here. We are positive to the idea of a mosque that looks like a mosque. I think that the politicians have listened a little bit extra to the Christian Churches when it comes to this. ${ }^{49}$

Inter-religious co-operation is becoming more institutionalised and hence also influences the physical location of Islam in Sweden. One example is the Christian-Muslim Social Service Centre in Nacka, Stockholm. As a joint venture of the Stockholm City Mission, the Church of Sweden Parish, The Muslim Association and St Konrad Catholic Church, The Well [Källan], as it is named, offers counselling and advice on practical matters that would normally be provided by public authorities. A social worker and a deacon work at the support centre, and they offer consultations with a priest from the Church of Sweden or the Catholic Church or with an imam. There is also a prayer room that is open to anyone. The Well is not a public authority, so the visitors may remain anonymous. ${ }^{50}$ In a similar manner,_common activities have been organised between the Christian and Muslim faith communities in Rosengård, Malmö: for example, in a joint celebration of the Swedish National Day. ${ }^{51}$ The event invitation, decorated with an illustration of the Malmö Mosque, was published in the Church of Sweden parish newsletter. ${ }^{52}$ 


\title{
ISLAMIC CENTER
}

INBJUDAN

\author{
Välkomna att fika \\ Sverige nationaldag \\ hos oss på \%slamic Center \\ söndagen den 6 juni , kl 11.00
}

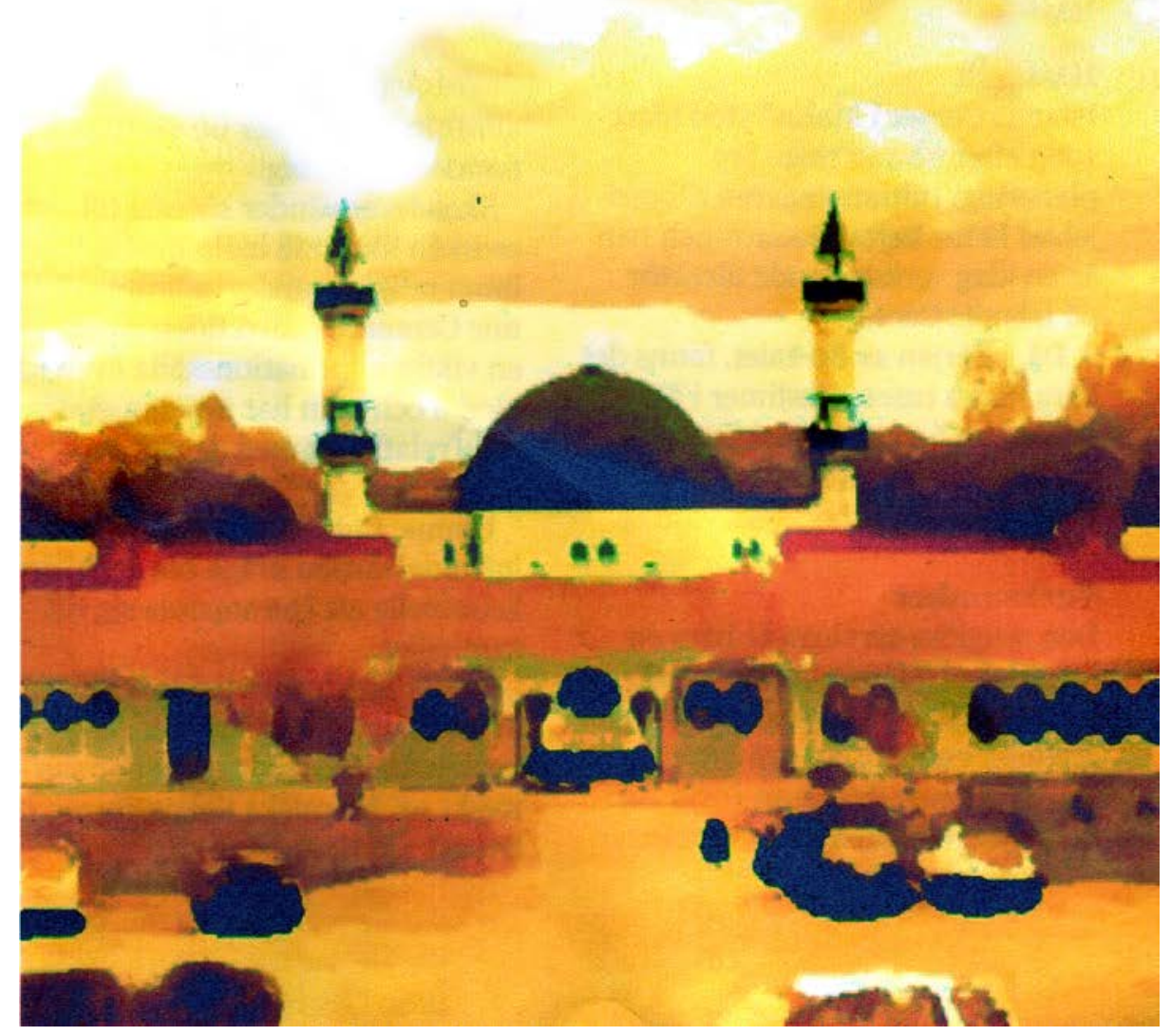

(Figure 1. Invitation from the Islamic Center to the Church of Sweden Parish in Västra Skrävlinge, Skåne [Scania], Sweden) 
One spectacular exception to the many basement mosques is the conspicuous Stockholm Mosque, which is located in the very centre of Södermalm (South Stockholm). Zayed bin Sultan Al Nahyan's Mosque [wedish: Zaid Ben Sultan Al Nahayans moské, Arabic: جامع ز ايد بن سلطان آل نهيان], commonly known as the Stockholm Mosque [Stockholms moské] or the Stockholm Grand Mosque [Stockholms stora moské], is the largest mosque in Sweden. Inaugurated in year 2000, the Mosque is administered by the Islamic Association in Stockholm. After consulting Islamic leaders, the city council in Stockholm decided in March 1995 to convert the old electric power station Katarinastationen [the Katarina Station] into a mosque. The building, designed by the Art Nouveau architect Ferdinand Boberg and completed in 1903, was already originally influenced by "Moorish" Islamic architecture. Boberg became inspired after a visit to Morocco and turned the building toward Mecca_and gave it tall windows with vaults. ${ }^{53}$ Easily reached by a well-connected subway system, the Mosque is first and foremost a house of prayer for the Muslims living in the Stockholm conurbation, but it is also important to other Muslims in Sweden, as it hosts annual elections and meetings with the national umbrella organisation Muslim Council of Sweden, in which 3,000 members participate.

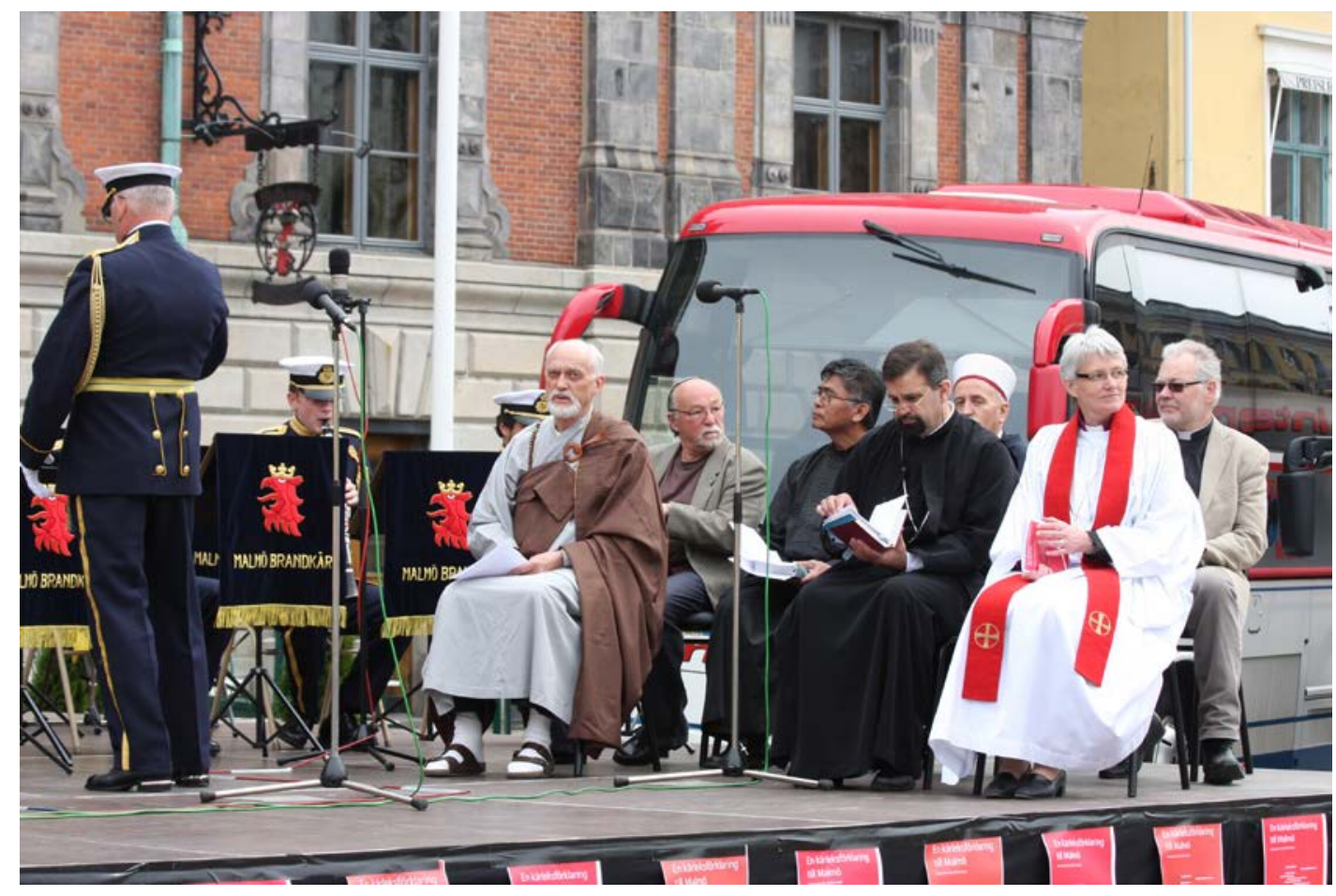

(Figure 2. The Stockholm Mosque, photo with permission of the photographer Gabriel Ehrnst Grundin, January 7, 2006.) 
Aside from being an important node of mental space for Muslims in Stockholm and all over Sweden, the Stockholm Mosque also functions as a community centre, increasingly becoming a resource not only for worship and social intercourse but also for developing contacts with non-Muslims:

This is a very special mosque, because it is so centrally located. There are many advantages with a central location [...] This environment is different. [...] We have changed some things, but the walls and ceilings are the same. It was built 1905, a hundred years ago. This very mosque is special. Tourists come here to watch, from France and Italy. It has become popular in Stockholm. Some people thought there could be problems, but instead it has enriched the area. ${ }^{54}$

In the other two major cities in Sweden, Malmö and Göteborg, there are also large mosques with functions similar to that of the one in Stockholm, although their locations are not as central and the buildings are not as traditional. Whereas the large Stockholm Mosque is located in a crowded area in the city centre, the Islamic Center Mosque in Malmö is located close to the large, multi-ethnic neighbourhood of Rosengård, much like the major mosque in Hisingen, Göteborg, which is in an area that includes a number of large multi-ethnic neighbourhoods. In addition, basement mosques and other provisional mosques are also quite frequent in these types of neighbourhoods. There are also physically identifiable, "real” mosques in Uppsala, Umeå and other cities. Thus, the availability, proximity, and visibility of sacred places for prayer and other faith ceremonies for Islamic believers in Sweden are gradually improving. Even in smaller towns, mosques are becoming more common. For example, in the municipality of Flen (which has approximately 6,300 inhabitants), an old Pentecostal church building was recently sold to the Alhouda Muslim Centre. ${ }^{55}$

\subsection{Imaging Muslim identity in Sweden}

In the last few decades, Sweden has transformed from an ethnically and religiously homogeneous society to a pluralist multi-ethnic society, and this transition has had implications for the range of faiths practiced in the country. Although the political and popular support for this development has been fairly strong, there remain well-documented instances of structural discrimination and racist tendencies that affect employment, education and income. ${ }^{56}$ American geographer Alan Pred, a frequent visitor to Sweden, described racism as "a spectre haunting Sweden" more than ten years ago. ${ }^{57}$ Despite these and other critical views of the official rhetoric and policies regarding immigrants, Sweden is fairly welcoming compared to many other European countries, although the entrance of the antiimmigration, anti-Islamic party, the Sweden Democrats [Sverigedemokraterna], into the 
Riksdag (the parliament) as a result of the September 2010 elections also reveals the presence of negative, racist sentiments directed against Islamic culture within the Swedish population. ${ }^{58}$ At the moment of writing, for example, media headlines in Sweden report on the daily harassment of Somalian children and families in a southern village. ${ }^{59}$

How do Muslims in general and the Muslim congregations in particular react to these challenges? How do they reconsider their identity in their new homeland? There is no single Muslim identity that includes all of the currents of Muslim faith in Sweden. ${ }^{60}$ Neither is this identity a product of discourses produced by the Muslim community alone, as it is embedded in a hegemonic non-Muslim discourse about Muslims in Sweden, which in turn has a strong influence upon Muslim identity in Sweden. As argued by Kinnvall and Nesbitt-Larking, “At its most basic level, an identity is how one comes to define oneself, one's core membership and reference groups, notably those from whom one distinguishes oneself”. Furthermore, "Depending upon the social structure, identities are more or less in a process of change through time and across space". ${ }^{61}$ In the beginning of this article, we borrowed the two authors' three ideal strategies of identity formation among Muslim immigrants: retreatism, essentialism, and engagement. ${ }^{62}$ Drawing upon our interviews with imams and other Muslim leaders, as well as written material published by Muslim congregations, we find evidence of a strategy of engagement, i.e., an attempt "to deal with differences through bargaining, openness toward the other, collaboration, and dialogue [... ] Engagement implies passion and commitment and a determination to find and express one's voice" ${ }^{63}$ We will provide a few examples of this stance that are more or less related to the mosque as a mental node for identity construction among Muslims in Sweden.

The Muslim Adult Education Association, Ibn Rushd ${ }^{64}$ was founded in 2,007 and is one of ten Adult Education Associations recognised by the Council of Adult Education. This association links the Swedish Muslim community to the Swedish corporatist tradition, with strong ties between civil society/popular movements and the state. A current project by Ibn Rushd, “The promotion of Islamic Peace Culture”, is targeting Muslim youth across the country, training them to become Peace Agents:

The long term aim is to combat islamophobia (fear and animosity towards Islam, mainly by people in the West) and Westphobia (fear and animosity towards the West, mainly by Muslims). Within the framework of the project a foundation has been laid for a Muslim peace movement. ${ }^{65}$ 
The stated intention of the program is to eradicate prejudice and to construct a Muslim identity within the Swedish context by emphasising the emergence of a new Muslim peace movement. Notably, in this process, the idea of a non-peaceful Muslim movement is also implicitly recognised as valid.

Mosques and other Islamic centres can offer advice and support on matters of great diplomatic concern. Addressing the caricatures of Mohammed re-published by a Swedish daily newspaper, the Stockholm Mosque met with the Prime Minister and other government officials. "We contributed to limiting the problem, so that it would not become the same as in Denmark”, Abdallah Salah says, referring to the racist, Islamophobic, antiimmigrant social unrest that developed after the publication of similar material there. ${ }^{66}$

Fredrik Reinfeldt [the Prime Minister] asked us 'what can we do to avoid things to become the same as in Denmark?' We told him 'you don't need to do anything; we have already sent press releases to all the international news media'. International media contacted the Mosque to get statements on the development but the Mosque did not want to inflate the issue. 'This is Sweden, this is a local problem, we can handle it here and we are capable of solving this', was our message to the journalists.

Another example of this type of “diplomatic” initiative arose in 1992, when two Swedish citizens were captured in Iraq. Imams from the congregation in Stockholm were sent to Iraq to negotiate their release. Referring to this incident, Abdallah Salah says,

Muslims are not only Muslims here [in Sweden], they are new Swedes; they can become fantastic ambassadors in the future in other countries. And that does not only go for politics, but also for economy. Knowledge of the language and the culture enables better relations. ${ }^{67}$

Abdul Rashid Mohamed, an imam and teacher of Islam and a representative of the Islamic Association in Göteborg, explains how Islamic organisations look at their role in trying to develop an Islamic identity in a new social and religious context: ${ }^{68}$

It is difficult to separate what is secular and what is religious with Islamic organisations. Everything is everything. Belief is not separate from everyday life. We are kind of "seculareligious" ["sekulareligiösa”]. We are doing everything, we are active in Islamic rituals, ramadan, solemn celebrations [...] We are pursuing a lot of activities, the Islamic information association, the Islamic school.

Notably, consistent with Islamic tradition and practice Muslim mosques and congregations are strongly male dominated in terms of their leadership and management. ${ }^{69}$ However, Muslim women may still be very active in everyday matters outside the mosque. This type of 
“invisible activity” has been documented by historian Klara Folkesson in a study of Muslim women in a Swedish neighbourhood. ${ }^{70}$ In the local branch of Verdandi, a non-religious temperance movement with roots as far back as 1896, the long-time unemployment among Muslim women was mitigated by the opportunity to participate in activities such as sewing, baking, and Swedish language and cultural education. Within their local social networks, these Muslim women experienced a sense of belonging and identity that made them better equipped for life in their new country.

Increasingly, the Swedish media report on everyday activities undertaken by Muslim women: for example, one Muslim woman created a program for training 120 girls in basketball in the strongly multi-cultural, multi-ethnic, and multi-religious neighbourhood of Vivalla, Örebro. As the (male) manager of the neighbourhood centre comments,

Malika mirrors the women here and is one of them. As Muslim and woman they have a special trust in her. She is a star in the neighbourhood. ${ }^{71}$

These two examples showing Muslim women strongly engaged in social activities outside the mosque can be seen as expressions of the ambition to create a Muslim identity that also includes women, who generally stand in the shadow of men inside the mosque.

\subsection{The mosque as a community centre}

The Islamic congregations that are studied here extensively use non-religious activities such as sports, adult education, study circles and other social activities to indirectly prevent social exclusion and promote integration. ${ }^{72}$ In this context, the mosque is a crucial arena in which people can develop friendships, connections with others and a sense of belonging. In terms of the social capital produced, these experiences can be defined as both bonding and bridging. As shown by Ley and others, first-generation immigrants often stick together upon their arrival, developing a sense of community within their new country, and then gradually begin "a transition from internal bonding to external bridging capital”. ${ }^{73}$ Often, activities serve as both bonding and bridging; for instance, developing computer skills may help someone to stay in touch with former fellow countrymen but may also help the person to attain a new job in Sweden. Other roles include helping and representing people who for one reason or another have experienced problems with the public authorities. The Stockholm Mosque provides support on an individual basis and refers people to local government institutions or other statutory, FBO and NGO organisations when necessary. ${ }^{74}$ 
Thus, aside from being important locations for worship and celebration, mosques also function as community centres and foster contact with non-Muslims:

There is in essence no limit for what kind of activities that can be carried out at the Mosque. The problem is that a mosque is immediately associated with religion. But a mosque is more like a Community Centre [Folkets Hus]. Out of the 50-60 activities organised at the Mosque each week a maximum 10 per cent has religious content. People want to spend time in the Mosque also doing other things; it is a good environment where people feel comfortable. ${ }^{75}$

For example, although the Stockholm Mosque is basically a house of prayer, a number of other cultural and welfare activities have developed there and are now thriving. These activities include marital support sessions, youth activities, female gym classes and swimming lessons. "We are part of society. Saving souls is not enough", the president of the Islamic Association in Stockholm Abdallah Salah told us in an interview. ${ }^{76}$ Every day, as many as eight groups of approximately 30 people each, predominantly teachers and their school classes, visit the mosque that is also frequently visited by politicians and public servants. In addition, the mosque is also contacted by homeless people and people with drug problems, who congregate around the adjacent Medborgarplatsen [which literally means "Citizen Square”] and its subway station. During Ramadan, some of these people also stay overnight in the mosque. Because the mosque location is close to the subway, Muslim people from other parts of the city and visitors from other parts of Sweden and abroad can easily reach the Stockholm Mosque: "The mere location of the Mosque at the Centre of Stockholm is the greatest integration project”. ${ }^{77}$ Consistent with this ideal, the goals of the United Islamic Congregations in Sweden are as follows: "integration of Muslim people in society”, "helping Muslims to keep their cultural, social and religious identity” and "working as a bridge builder between the Swedish authorities/majority population and Muslims”. ${ }^{78}$

Some religious Muslim practices are adjusted to a Swedish context; for instance, "we try to start Ramadan at the same time for all Muslims = the Swedish way". ${ }^{79}$ A spokesperson for Islamic Association in Göteborg says,

the role of our organisation is for our members to feel safe and secure socially, in society and with Islam. That is a prerequisite for peace for the ethnic or religious minority, but also for the society at large. ${ }^{80}$

The speaker recalls developments in France in which there have been uprisings in poor neighbourhoods with large Muslim populations and then continues: 
The reasons for the disturbances are that the people lack safety and a sense of justice. We need to find ourselves a room, where we can know who we are. If one knows one's own base, it is easier to feel secure and to live in peace. ${ }^{81}$

According to Abdallah Salah, the Mosque is the best place to reach practicing Muslims because they "don't go to the night clubs, pubs and other places where many Swedes go". Every week, between 2,000 and 3,000 people participate in the Friday prayer at the Stockholm Mosque. "The Friday pray is a great platform for integration”, says Salah, who continues as follows:

Take for example the work carried out on the black labour market. The Tax Agency has struggled for years to communicate the importance of not accepting illicit employment without social security costs. But if the Imam says 'illicit work is haram' more people listen, which means that a lot of problems could be prevented this way. ${ }^{82}$

The mosque thus is a place where important community service information is communicated, which also helps to contribute to the creation of a Muslim identity adapted to the Swedish context.

\section{5}

\section{Conclusion: constructing a Muslim identity in Sweden}

Most Muslims in Sweden are first- or second-generation immigrants. This means that the people who gather in the mosques come from very different backgrounds, speak different languages and bring with them different Islamic customs. For this reason, many Swedish Muslim congregations, leaders and committed individuals work hard to build a Muslim identity that is consistent with Swedish society. Hence, the presence of real mosques has great material and symbolic importance. As illustrated by the interviews quoted in this article, basement mosques and other provisional mosques are important as places where Muslims can meet and practice their faith together. However, "[A]s long as we are in a basement, we do not really exist”. ${ }^{83}$

Mosques are important not only as sacred places in a strictly religious sense but also as intellectual and social hubs for Muslims: places for creating both bonding and bridging social capital. ${ }^{84}$ In other words, they are places where a Muslim identity can be sown and cultivated, as vividly expressed by a leading representative of the Islamic community, who mentions three crucial functions of Islamic organisations in Sweden: ${ }^{85}$

The most important goal is integration, to integrate Muslims into the Swedish society. The organization also works for Muslims to keep their identity as Muslims, in terms of culture, religion and socially. Third is that the organisation functions as a bridge 
between the majority of Swedes and Muslims [...] One should co-operate, be on speaking terms and have acceptance. Then it will be complicity, complicity creates dialogue, and dialogue means that we feel together. I think Sweden is like a boat on which we are all on board. We should unite to foster peace so that it will be a good livelihood for all of us.

Notably, what is expressed in this quotation is not an unconditional will to integrate or submit Muslims to the Swedish society or an emphasis on assimilation [assimilering] - neither is it considered essential to unconditionally preserve or protect a "pure" or "real” form of Muslim identity. The aim is not even to merge Muslim identity with a perceived Swedish national identity. Instead, the task at hand involves accommodation [jämkning/ömsesidig anpassning], as one of our spokesmen said:

We want to get more understanding from society. That Islam is not considered an alien religion. That's what complicates the situation for us Muslims. [...] Islam should be a self-evident religion. If someone wants to become a Muslim then it should be the same thing as for Christianity or Buddhism, why look at it differently? [...] Freedom of speech is parallel to religious freedom. One should not oppress religion in the name of freedom of speech. Sweden has become very good at this, but it is still difficult. There is this wall saying "alien religion", that is what we find problematic". ${ }^{86}$

Here, the interviewee refers to a general discourse in society in which Islam represents the exception to the Swedish Lutheran norm and in which individual Muslims are accepted but Muslims as a collective are not.

In this emerging interreligious dialogue concerning basic values and identities, the Mosque, including its provisional forms, is a crucial arena not only for preserving Muslim identity and developing internal religious and ethnic and cultural bonds but also for creating bridges to the secular Lutheran society in Sweden. As argued by Kinnvall and Nesbitt-Larking, this process may be understood as one of desecuritisation, i.e., a process of removing a previously conflict-ridden issue "from the realm of existential survival, thus making it easier to resolve through cooperative and/or routine means of problem solving in civil society”. ${ }^{87}$ In line with this argument, Hetty Zock reminds us that “[C]ultural misunderstandings abound, and [...] this goes especially for the conflicts in which religious and identity elements are involved. Therefore, individuals are required to develop strong communicative skills and imaginative, creative capacities in order to be able to deal with diversity”. ${ }^{8}$

In summary, as illustrated in this article, mosques not only function as inward-looking markers of religious faith but also operate as arenas for developing links to the Christian and secular parts of Swedish society. Mosques are important as platforms for creating bonding 
and bridging capital for Muslims in Sweden and nodes of engagement with other inhabitants in Swedish society. Notably, this conclusion does not suggest that in Sweden, as elsewhere, there are not Muslims who view it as socially and politically desirable to separate Muslims from non-Muslims: there remain "extremists [who] articulate and aggregate dissenting voices, thereby amplifying the perceptions that globalization and discourses on terror are directed against them". ${ }^{89}$ In other words, some Muslims in Sweden, as in other societies, employ strategies of retreat or essentialism as well as engagement, although our focus in this article has been on the latter in particular, as expressed by imams and in official Muslim documents that address the relationship between Islam and Swedish society.

\section{Acknowledgements}

The article draws largely upon research pursued within the context of FACIT - FaithBased Organizations and Exclusion in European Cities - a comparative research project funded by the European Commission's Seventh Framework Programme. Based on a common research agenda, researchers from seven European countries investigated the present role of Faith-Based Organizations (FBOs) in tackling different forms of social exclusion in urban contexts. A detailed presentation of the research framework, methods and sources are given in Danielle Dierckx, Jan Vranken and Wendy Kerstens (eds), Faith-based Organisations and Social Exclusion in European Cities. National Context Reports. (Leuven/Den Haag: Acco, 2009) and Ingemar Elander and Charlotte Fridolfsson, Faith-based Organisations and Social Exclusion in Sweden (Leuven/Den Haag: Acco, 2011). We are grateful to Andreas Thörn and other colleagues at the Centre for Urban and Regional Research, Örebro University for useful comments on earlier versions of this article.

\section{Notes}

${ }^{1}$ Daniel Sjödin, Tryggare kan ingen vara. Migration, religion och integration i en segregerad omgivning [You cannot be more confident. Migration, religion and integration in a segregated surrounding] (Lund: Lund University, 2011) [PhD Thesis]; Marike de Haardt, Making sense of sacred space in the city? Pp. 163-182 in Arie L. Molendijk, Justin Beaumont and Christof Jedan (Eds) Exploring the Postsecular. The Religious, the Political and the Urban. (Leiden 
and Boston: Brill, 2010); Catarina Kinnvall and Paul Nesbitt-Larking, The political psychology of (de)securitization: place-making strategies in Denmark, Sweden, and Canada. Environment and Planning D: Society and Space. [Published online 18 August 2010]; David Ley (2008) The immigrant church as an urban service hub. Urban Studies 45 (10), pp. 20572074.

${ }^{2}$ Orlando Mella, Searching for the Sacred. A Comparative Study of Popular Religiosity among Refugees in Sweden (Stockholm: CEIFO Publications, 1996).

${ }^{3}$ Catarina Kinnvall and Paul Nesbitt-Larking, The Political Psychology of Globalization. Muslims in the West. (Oxford: Oxford University Press, 2011), quotation on p. 196.

${ }^{4}$ Magdalena Nordin, Religiositet bland migranter: Sverige-chilenares förhållande till religion och samfund [Religiosity among migrants: Sweden-Chileans relationship to religion and congregations] (Lund: Lunds universitet, 2004).

${ }^{5}$ Ung kärlekshistoria som utspelar sig i muslimsk vardag - höstsamtal [Young love story as it happens in Muslim everyday life - autumn conversation], Nerikes Allehanda [Swedish daily] 23 November, 2011. Cf. this argument by Pieter Bevelander and Jonas Otterbeck,

Islamophobia in Sweden: politics, representation, attitudes and experiences, in Marc Helbling (ed) Islamophobia in the West: Measuring and Explaining Individual Attitudes (London and New York: Routledge, 2012), p. 72: "Merely the diversity of origins - national, ethnic, religious etc., - opens up a pluralism of Islams being practiced, not to mention individual preferences...”.

${ }^{6}$ Anders Bäckström and Grace Davie, Welfare and religion in Europe: Themes. Theories and tensions. In Anders Bäckström, Grace Davie, Ninna Edgardh and Per Pettersson (eds) Welfare and Religioin in $21^{\text {st }}$ Century Europe. Volume 2. (Farnham, Surrey: Ashgate. 2011).

${ }^{7}$ Jocelyn Cesari (2005), Mosque conflicts in European cities: introduction. Journal of Ethnic and Migration Studies 31 (6), p. 1018.

${ }^{8}$ Cesari, Mosque conflicts, p. 1018.

${ }^{9}$ Cesari, Mosque conflicts, p. 1018.

${ }^{10}$ Peter Mandaville (2009), Muslim transnational identity and state responses in Europe and the UK after 9/11: political community, ideology and authority. Journal of Ethnic and Migration Studies 35 (3), pp. 491-506.

${ }^{11}$ Veit Bader (2007), The governance of Islam in Europe; the perils on modelling. Journal of Ethnic and Migration Studies 33 (6), pp. 871-72.

${ }^{12}$ Bader, The governance of Islam, p. 883.

${ }^{13}$ See for example case studies in Cesari, Mosque conflicts, and in a special issue of Journal of Ethnic and Migration Studies 35 (3) on Muslims and the state in the post-9/11West. Notably, no Scandinavian countries are included in these two special issues on Islam in Europe. However, the broader issue of Muslim identity in Sweden and five other countries is the topic of Kinnvall and Nesbitt-Larking, The Political Psychology of Globalization.

${ }^{14}$ Gert Pickel and Olaf Müller, Introduction - the comparative empirical view on religion and religiosity. Pp. 7-12 in Gert Pickel and Olaf Müller (Hrsg.) Church and Religion in Contemporary Europe. Results from Empirical and Comparative Research. (Wiesbaden: VS Verlag für Sozialwissenschaften, 2009) As noted by Gregor McLennan “post-secular” is a very crude term, intellectually covering a broad spectrum of stances, and certainly not excluding the simultaneous presence of secular as well as post-secular tendencies in different real-world contexts. Gregor McLennan (2010) Spaces of postsecularism. Pp.41-62 in Molendijk et al. Exploring the Postsecular.

${ }^{15}$ Kinnvall and Nesbitt-Larking, The Political Psychology of Globalization, p. 39.

${ }^{16}$ See for example Justin Beaumont and Paul Cloke (eds) Faith-based Organizations and Exclusion in European Cities (Bristol: Policy Press, 2012). 
${ }^{17}$ Lars-Erik Olsson, Marie Nordfeldt, Ola Larsson and Jeremy Kendall, Sweden: when strong sector historical roots meet EU policy processes. Pp. 159-183 in: Jeremy Kendall (ed) Handbook on Third Sector Policy in Europe and Organised Civil Society (Cheltenham: Edward Elgar, 2009; quotation, p. 164).

${ }^{18}$ Ingemar Elander and Charlotte Fridolfsson, Faith-based Organisations and Social Exclusion in Sweden (Leuven/Den Haag: Acco, 2011).

${ }_{19}$ The article is to a great extent based on research pursued in the context of the European Commission $7^{\text {th }}$ Framework Programme FACIT (cf. Acknowledgements), including structured face-to-face interviews with imams at mosques in Gothenburg, Malmö and Stockholm. One imam at the Stockholm Mosque was also interviewed by a cross-evaluation team, including researchers from three other European countries (details about the interviews are given in Elander and Fridolfsson, Faith-based Organisations, Appendix I). The interviews were complemented by articles and written material picked from newspapers and the internet as well as recent secondary research literature. We are well aware of the possibility that the interviewed imams, as official representatives of Islam in Sweden, may - by intention or unintended - have given a biased view of imams and Muslim immigrants wanting to adapt to Swedish attitudes and habits. However, as our intention was rather to catch, and critically discuss, the publicly presented Muslim view we do not see this as a serious problem. Of course, among imams and Muslim immigrants practicing Islam at the mosques there are great differences in approaches to identity formation (see for example Kinnvall and NesbittLarking, The Political Psychology of Globalization, p. 152).

${ }^{20}$ The term "blue-and-yellow Islam", used by at least one other scholar, we find misleading as it may be interpreted as a Muslim will to subordinate itself to some sort of "real Swedish culture”, i.e. a very dubious term itself. Cf. Susanne Olsson, Religion in the public space: 'blue-and-yellow' Islam in Sweden. Religion, State and Society 37 (3), pp. 277-289.

${ }^{21}$ Svenska Kyrkan. Church History. [online] Available from: http://www.svenskakyrkan.se/default.aspx?id=657802 [Accessed 24 January 2012]. ${ }^{22}$ Mattias Gardell, Islam och muslimer i Sverige [Islam and Muslims in Sweden] (Stockholm: Arvsfonden, 2010), p. 6.

${ }^{23}$ Pippa Norris and Ronald Inglehart, Sacred and Secular: Politics and Religion Worldwide. (New York: Cambridge University Press, 2004), p. 90; Gallup, What Alabamians and Iranians have in common. [online] Source. Available from: http://www.gallup.com [First published on 9 February 2009,Accessed 25 August 2010]

${ }^{24}$ The membership fees are collected for the parish through the tax ballot from their respective members. Due to its size, financial strength, and physical presence in each local community, no other faith-based organization enjoys the same independence in relation to government as the Church of Sweden.

${ }^{25}$ Dagens Nyheter [Swedish daily], Svenska kyrkan krymper snabbare [Church of Sweden shrinks faster] http://www.dn.se/nyheter/sverige/svenska-kyrkan-krymper-snabbare [Accessed 25 February 2011]; Svenska Kyrkan (2011) Inträden i och utträden ur Svenska kyrkan år 1970-2010 [Enrolment in and exit from the Church of Sweden 1970-2010] . Source: http://www.svenskakyrkan.se/default.aspx?id=645562 [Accessed 7 August 2011] ${ }^{26}$ Migrationsverket [The Migration Board] Migration 2000-2010. Rapport 2010: 2.[online] Available from: http://www.migrationsverket.se/info/start_en.html [Accessed 28 September 2010]

${ }^{27}$ Utbildningsradion [Swedish Educational Broadcasting Company] Muslimer i Sverige [Muslims in Sweden], [online] Available from: www.ur.se/Ung/Amnen/SO/Religion/Islam/Islam-i-Sverige [Accessed: 7 August 2011] 
${ }^{28}$ SST (2010) Nämnden för Statligt Stöd till Trossamfund [Swedish Commission for Government Support to Faith Communities] [online] Available from:

http://www.sst.a.se/inenglish.4.7f968fc211eeec933de800011945.html [Accessed 26 August 2010]; Göran Larsson and Åke Sander, Islam and Muslims in Sweden: Integration or Fragmentation?: A Contextual Study. (Berlin and Münster: Lit-Verlag, 2008).

${ }^{29}$ Bevelander and Otterbeck, Islamophobia in Sweden, p. 72.

${ }^{30}$ SST 2010.

${ }^{31}$ SOU[Government Commission Report] Staten och imamerna - Religion, integration, autonomi. [The state and the imams - religion, integration, autonomy] Report 2009: 52, p. 42.

32 Ann-Catrin Andersson, Identity Politics and City Planning. The Case of Jerusalem (Örebro: Örebro University, Örebro Studies in Political Science 30, 2011) [PhD thesis]; Philip Sheldrake, Spaces for the Sacred Place, Memory and Identity. (Baltimore: Johns Hopkins University Press, 2011).

33 Yi-Fu Tuan, Space and Place. The Perspective of Experience (Minneapolis and London: University of Minnesota Press, 1977) p. 150.

34 Justin Beaumont, Transcending the particular in postsecular cities. In Molendijk et al., Exploring the Postsecular, p. 3, 9.

${ }^{35}$ Gemma T. Cruz, Into the Deep: A Theological Exploration of the Struggle of Filippina Domestic Workers in Hong Kong (Nijmegen: Radboud University, 2006), p. 89. [Doctoral thesis]

${ }^{36}$ Attending a game at Anfield Road in Liverpool one is struck by the collectively orchestrated rituals framing the whole event, including the "exit gospel”, "You'll never walk alone" sung by 30-40 000 Liverpool supporters.

37 Marike de Haardt, Making sense of sacred space in the city? Pp. 163-182 in Arie L. Molendijk, Justin Beaumont and Christof Jedan (eds) Exploring the Postsecular. The Religious, the Political and the Urban (Leiden and Boston: Brill, 2010), p. 170.

${ }^{38} \mathrm{Kim}$ Knott, Cutting through the postsecular city: a spatial interrogation. In Molendijk et al, p. 24.

${ }^{39}$ Edward Soja, Thirdspace: Journeys to Los Angeles and Other Real-and-Imagined Places (Blackwell: Oxford, 1996); de Haardt, Making sense.

${ }^{40}$ Cf. Knott, Cutting through.

41 de Haard, Making sense, p. 174.

${ }^{42}$ Knott, Cutting through, p. 35; cf. Henri Levebvre, Space and the state. Pp. 223-253 in Neil Brenner and Stuart Elden (eds), State, Space, World: Selected Essays. Henri Levebvre, Selected Essays. (Minneapolis and London: University of Minnesota Press, 2009), pp. 224-25. ${ }^{43}$ Fuat Deniz, En minoritets odyssé. Det assyriska exemplet [The odyssé of a minority. The Assyrian example] Örebro Studies in Sociology. (Örebro: Örebro universitet, 2001). [PhD Thesis]

${ }^{44}$ Marcus Johansson and Thomas Uddin, Frihet och tolerans. Debatt och konflikt kring lokaliseringen av en syriansk-ortodox kyrka och ett islamiskt kulturcentrum i Örebro [Freedom and tolerance. Debate and conflict on the localisation of a Syrian-Orthodox Church and an Islamic Cultural Centre in Örebro] (Örebro: Örebro University, Centre for Housing and Urban Research, 1994).

45 Johansson and Uddin, Frihet och tolerans.

46 As quoted on pp. 124-25 in Göran Larsson and Åke Sander, From cellar to dome and minaret in Helena Holgersson, Catharina Thörn, Håkan Thörn and Mattias Wahlström (eds) (Re)searching Gothenburg. (Göteborg: Glänta Produktion, 2010).

${ }^{47}$ Mostafa Kharraki, interview by Charlotte Fridolfsson, The United Islamic Congregations in Sweden, Stockholm, 29 January, 2009. 
${ }^{48}$ Dagens Nyheter [Swedish daily] Ny moské i Skärholmen snart verklighet [New Mosque in Skärholmen soon a reality] 15 April 2011.

${ }^{49}$ Kerstin Billinger, Kerstin (2009), interview by Charlotte Fridolfsson, Church of Sweden Parish Skärholmen. [Svenska kyrkan Skärholmens församling] 1 April 2009.

${ }^{50}$ Marika Markovits, interview by Charlotte Fridolfsson, Stockholms stadsmission [Stockholm City Mission], 15 April, 2009.

${ }^{51}$ Dagen [The Day - Swedish daily on Christian foundation; 17000 subscribers] Gammal pingstkyrka blir moské [Old Pentecostal church becomes a mosque] 10 May 2011.

52 Västra Skrävlinge Församling, Församlingsblad No. 2., 2010 [Newsletter No. 2 from the Västra Skrävlinge Parish, Malmö]

53 Stockholms Moské [Stockholm Mosque, startpage. [online] Available from: http://hem.spray.se/kifah.f [Accessed 29 June 2010]

${ }^{54}$ Kharraki, interview, 2010.

${ }^{55}$ Protests from congregation members were countered by the pastor of the Christian local congregation: "What would Jesus have done? I can't believe that he would have closed the door, obviously the message of love must also pertain to Muslims. We try to build good relations to all, and in the long run I believe this will lead to something better than if we had said no" (Dagen, 10 May, 2011). The incident is described and discussed more in detail by Andreas Thörn in an unpublished paper, 'The Filadelfia Church in Stockholm' (Örebro University, January 2012).

${ }^{56}$ Magnus Dahlstedt, Utbildning, arbete, medborgarskap: strategier för social inkludering i den mångetniska staden [Education, work, citizenship: strategies for social inclusion in the multiethnical city] (Umeå: Boréa, 2007). Roger Andersson and Irene Molina, Racialization and Migration in Urban Segregation Processes. Key issues for critical geographers. In Jan Öhman and Kirsten Simonsen (eds) Voices from the North - New Trends in Nordic Human Geography, (Aldershot, Hants: Ashgate, 2003); Ingemar Lindberg and Magnus Dahlstedt (eds.), Det slutna folkhemmet: om etniska klyftor och blågul självbild [The closed People’s Home: on ethnic cleavages and blue and yellow self-image] (Stockholm: Agora, 2002). Abdul Khakee and Markus Johansson, Not on our doorstep: immigrants and 'blackheads' in Sweden’s urban development. In Abdul Khakee, Paolo Somma and Hugh Thomas (eds) Urban Renewal, Ethnicity and Social Exclusion in Europe. (Aldershot, Hants: Ashgate, 1999).

${ }^{57}$ Alan Pred, Even in Sweden.Racisms, Racicalized Spaces, and the Popular Geographical Imagination. (Berkeley and Los Angeles: University of California Press, 2000).

${ }^{58}$ Elander and Fridolfsson, Faith-based Organisations, pp. 37-38; Bevelander and Otterbeck, Islamophobia in Sweden.

${ }^{59}$ Quotations reported by one newspaper: “They threw gravel on me, they pushed me when I walked with my little child, they shouted 'bloody nigger'”; “The Somalians scream at us too, they fight at school, we have been depicted as the worst kind of racists.” The newspaper itself concludes: "Forserum is a divided village that tries to clean its racist stamp". Source: "Forserum - en delad by" [Forserum - divided village], Aftonbladet 26 August 2012.

60 "Merely the diversity of origins - national, ethnic, religious etc., - opens up a pluralism of Islams being practiced, not to mention individual preferences...”. Bevelander and Otterbeck, Islamophobia in Sweden, p. 72.

${ }^{61}$ Kinnvall and Nesbitt-Larking, The Political Psychology of Globalization, p. 56.

${ }^{62}$ Kinnvall and Nesbitt-Larking, The Political Psychology of Globalization, p.196.

${ }^{63}$ Kinnvall and Nesbitt-Larking, The Political Psychology of Globalization, p.160, 193.

${ }^{64}$ Named after the Muslim scientist/philosopher based in Cordoba, Spain, during the $12^{\text {th }}$ Century. The name is derived from the word 'Ibn' meaning son and 'Rushd' which means 
reason. Source: Ibn Rushd Educational Association. [online] Available from: http://www.ibnrushd.se/filer/ibnrushd_engelska.pdf [Accessed 30 November 2011] ${ }^{65}$ Ibn Rushd.

${ }^{66}$ Abdallah Salah, interview by Charlotte Fridolfsson, the Islamic Association in Stockholm, Stockholm Mosque, 12 March, 2009. The so called Cartoon Crisis in Denmark started on September $30^{\text {th }} 2005$ when the newspaper Jyllands Posten published a blasphemous picture of Mohammed. As for the following debates and conflicts, intimately related to the culture and ideology of "Danishness" [danskhet] see Larissa Bachora, Ingemar Elander and Charlotte Fridolfsson, Faith-based Organisations and Social Exclusion in Denmark (Leuven/Den Haag: Acco, 2011); Robert A. Kahn, Flemming Rose, the Danish Cartoon Controversy, and the new European Freedom of Speech. Legal Studies Research Paper Series No. 09-24 (Minnesota: University of St. Thomas, School of Law, 2009); Kinnvall and Larking,The political psychology of (de)securitization.

${ }^{67}$ Salah, interview 12 March 2009.

${ }^{68}$ Quotations from an interview with Abdul Rashid Mohamed at Römosseskolan 8 [The Römosse School] by Charlotte Fridolfsson, Gårdsten, Angered, 12th May 2010.

${ }^{69}$ Anne-Sofie Roald, The Mecca of Gender Equality: Muslim Women in Sweden, in Haifaa Jawad and Tansin Benn, Muslim Women in the United Kingdom and Beyond. Experiences and Images (Leiden/Boston: Brill, 2003).

${ }^{70}$ Klara Folkesson, Invisible Activity: The Case of Muslim Women Migrants in Fittja, Sweden. Pp. 115-140 in Frank Eckhardt and John Eade (eds)The Ethnically Diverse City. (Berlin, Berliner Wissenschafts-Verlag, 2011).

${ }^{71}$ Nerikes Allehanda [Swedish daily], Hon är årets idrottsledare [She is the sports leader of the year] Nerikes Allehanda 6 August 2010, p. 9. Malika Boulalla, born in Casablanca, was awarded the local sports journalists' grant "the sports leader of the year".

${ }^{72}$ Elander and Fridolfsson, Faith-based Organisations, pp. 46-53

${ }^{73}$ David Ley, The immigrant church as an urban service hub. Urban Studies 45 (10), 2008, pp. 2057-2074.

${ }^{74}$ Abdallah Salah, cross evaluation interview. The Islamic Association in Stockholm, Stockholm Mosque, 14 September, 2009.

${ }^{75}$ Salah, interview.

${ }^{76}$ Salah, cross-evaluation interview.

${ }^{77}$ Salah, interview.

${ }^{78}$ Kharraki, interview.

${ }^{79}$ Salah, cross-evaluation interview.

${ }^{80}$ Abdul Rashid Mohamed, interview by Charlotte Fridolfsson, Islamiska förbundet i

Göteborg [The Islamic Association in Göteborg], Angered, 12 May, 2009.

${ }^{81}$ Mohamed, interview.

${ }^{82}$ Salah, interview.

${ }^{83}$ Abd al Haqq Kielan, Imam and secretary of the Swedish Islamic Academy as quoted in Larsson and Sander, Islam and Muslims in Sweden, pp.124-125.

${ }^{84}$ As illustrated by Katarina Nylund in a study of local Muslim and Christian congregations, first generation immigrants commonly find these as a basis for strengthening their sense of belonging (bonding capital), whereas second generation immigrants may rather (or also) use their membership in these as a platform for linking themselves to and participate as citizens in society at large (bridging capital). Katarina Nylund, De religiösa samfundens betydelse som offentliga mötesplatser för människor i förskingringen [The importance of religious congregations as public meeting places for people in the Diaspora] Pp. 333-383 in Katarina Nylund (ed.) Periferin i centrum. Gränsöverskridande praktiker i Stockholms offentliga rum 
[The periphery at the centre. Border-crossing practices in the public spaces of Stockholm] (Göteborg: Daidalos, 2007).

${ }^{85}$ Kharrakhi, interview.

${ }^{86}$ Mohamed, interview.

${ }^{87}$ Kinnvall and Nesbitt-Larking, The political psychology of (de)securitization, p. 152.

${ }^{88}$ Hetty Zock, Voicing the self in postsecular society: a psychological perspective on meaning-making and collective identities. Pp. 131-146 in Molendijk et al. Exploring the Postsecular, p.132.

${ }^{89}$ Kinnvall and Nesbitt-Larking, The Political Psychology of Globalization, p. 152.

\section{Biographical note}

Charlotte Fridolfsson, $\mathrm{PhD}$, is a researcher and lecturer at Linköping University. She teaches graduate level and undergraduate courses in political science and gender studies. Her research interests include political theory, new social movements, gender politics and cultural studies. She is at the present involved in a interdisciplinary research project: Educational Pathways to Power (about the formal and informal education/learning among Swedish politicians). Deconstructing political protest (2006) was her $\mathrm{PhD}$ thesis. She is author (with Elander) of Faith community works in Sweden (in Beaumont and Cloke, 2012).

Ingemar Elander is professor of politics at the Centre for Urban and Regional Studies, Örebro University. His research interests cover urban governance in a broad sense as exemplified in publications on cities and climate change, environment and democracy, faith-based organisations and social exclusion in European cities, urban partnerships and public health. neighbourhood renewal and sustainability. He is currently involved in a research project on Sustainable development and neighbourhood renewal. He is co-editor of Urban Governance in Europe (Eckardt and Elander, 2009), and co- author of Faith-based Organisations and Social Exclusion in Sweden (Elander and Fridolfsson, 2011). 